\title{
Preparation and application of oyster shell supported zero valent nano scale iron for removal of natural organic matter from aqueous solutions
}

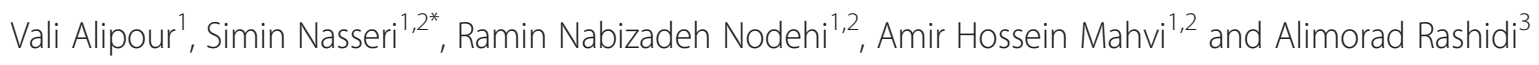

\begin{abstract}
Background: In this Research, oyster shell supported zero valent iron nanoparticles were prepared and applied for the removal of natural organic matters (NOMs) from aqueous solutions under different experimental conditions.

Methods: The nanoadsorbents prepared by wet impregnation method, then characterized using Scanning Electron Microscopy, Energy Dispersive Spectroscopy, X-Ray Fluorescence and BET analysis. Adsorption test was done in a batch reactor and the effects of different parameters such as initial adsorbate concentration, adsorbent dose, adsorption kinetic, pH, and temperature on removal of NOMs (humic acid as the indicator) were studied.

Results: Results showed that particle size of nanoadsorbent was in the range of 60-83 nm, and surface area and micropore volume as $16.85 \mathrm{~m}^{2} / \mathrm{g}$ and $0.021 \mathrm{~m}^{3} / \mathrm{g}$, respectively; the main elements of adsorbent were $\mathrm{Ca}, \mathrm{O}, \mathrm{Fe}$ and $\mathrm{Na}$ and lime, as high as about $94.25 \%$ was the main structural component of the total weight. Produced nanoadsorbent was not soluble in water. It was also shown that by increasing the nanoadsorbent dose from 0.5 to $5 \mathrm{~g} / 100 \mathrm{ml}$, the removal of humic acid increased from $62.3 \%$ to $97.4 \%$. An inverse relationship was found between initial concentration and adsorption capacity, so that a decreasing rate of 33\% for humic acid removal was observed by increasing $\mathrm{pH}$ from 5 to 10 . Temperature increase from $25^{\circ} \mathrm{C}$ to $40^{\circ} \mathrm{C}$, resulted in an increase in humic acid removal from $76.8 \%$ to $91.4 \%$ and its adsorption on the adsorbent could be better described by Freundlich isotherm $\left(n=0.016, K_{f}=0.013\right.$ and $\left.R^{2}=0.74\right)$. The most fitted adsorption kinetic model was pseudo-second order model.

Conclusions: The chemical structure of nanoadsorbent was proper and free from harmful substances. Despite the relative good condition of the effective surface, due to the large size of the shell, the overall micropore volume was low. Hence the qualitative characteristics the adsorbent caused the absorption capacity of humic acid to be low $(0.96 \mathrm{mg} / \mathrm{g})$.
\end{abstract}

Keywords: Humic acid, Iron supported oyster shell, Nanoadsorbent, Natural organic matters, Adsorption, Isotherm

\footnotetext{
* Correspondence: naserise@tums.ac.ir

${ }^{1}$ Department of Environmental Health Engineering, School of Public Health,

Tehran University of Medical Sciences, Tehran, Iran

${ }^{2}$ Center for Water Quality Research (CWQR), Institute for Environmental

Research (IER), Tehran University of Medical Sciences, Tehran, Iran

Full list of author information is available at the end of the article
} 

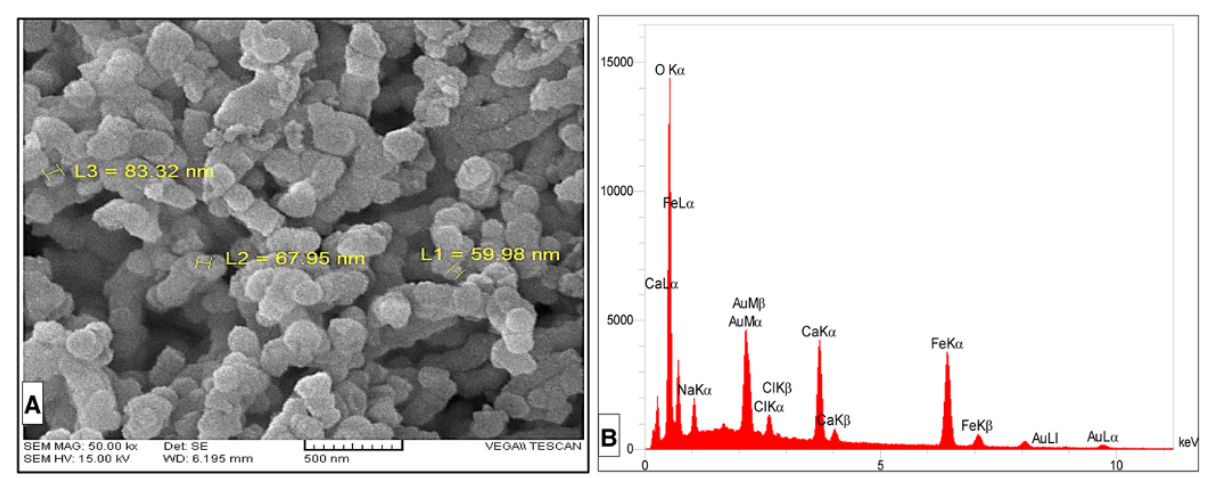

Figure 1 SEM (A) and EDS (B) of prepared nanoadsorbent. SEM (A) showing the Nanoscale particles and EDS (B) of prepared nanoadsorbent showing the main elements of adsorbent.

\section{Background}

Although surface water is an important natural resource used for many purposes, especially drinking, this resource generally contain natural organic matters (NOMs) so many scientific references have pointed out that more than 1500 different organic compounds are suspected to be present in drinking waters [1,2]. Naturally organic materials, a nonhomogeneous mixture of complex organic compounds, including; humic acids (HA), lipids, proteins, hydrophilic acids, carboxylic acids, amino acids, polysaccharides, and hydrocarbons are invariably present in surface and ground water resources, in dissolved or colloidal forms [3]. Various environmental and health problems have been reported that may be related to the presence of NOMs in natural waters, including; (a) the potential of NOMs have to cause undesirable color and taste [4]; (b) NOMs contributing the reactions with heavy metals and biocides to yield high concentrations of these substances and enhance their transportation in water [5]; (c) NOMs role in increasing coagulant and disinfectant dose requirements that lead to more sludge amounts; (d) in treatment plants, NOMs react with chlorine to form harmful organic compounds [4]; (e) NOMs are important factors in fouling which affect various applications of membrane processes [6]; and (f) their tendency to compete with low-molecular weight synthetic organic chemicals and inorganic pollutants, reducing their adsorption rates and equilibrium capacities $[7,8]$.

Considering harmful effects of NOMs on human health, these compounds should be eliminated from water before the chlorination process in drinking water treatment plants and it is important for the public health and drinking water industry to find reliable methods to remove a wide range of organic contaminants from water [9]. During the recent years, a large number of researches have been carried out on the NOMs removal from water in order to minimize its impacts on water quality $[3,10-14]$. Based on these researches, the most conventional options for NOM removal include membrane filtration and ion exchange [15,16], ozonation [17], biodegradation [18], ultrasound waves [19], adsorption, and coagulation [20]. Among the methods, membrane separation and adsorption were the most effective and available processes for removing NOMs from water [3]. High removal efficiency and no harmful by-products production are the main advantages for adsorption process and many kinds of adsorbents have been developed for the removal of humic acid from water.

During the past few years, nanoparticles have been proposed as a removal method for a wide range of pollutants from waters [21]. Some important nanoparticles in water treatment include metal-containing nanoparticles, carbonaceous nanomaterials, zeolites, and dendrimers [22]. As nanoscale zero-valent iron (NZVI) particles have unique reactive and sorption characteristics, they have received high attention for the treatment of contaminated waters $[23,24]$.

Several studies have been conducted using various materials such as mesoporous silica beads [25], carbon and titanium dioxide [26], chitosan beads [27], ceramic membranes [12], kaolin [28], and betonite [13] as a bases for nanoparticles. In southern coasts of Iran, there is a considerable amount of oyster shells which may have the potential to be used for a perfect bases for nanoadsorbents, and so far no study and

Table 1 Physical properties of the nanoadsorbent

\begin{tabular}{lll}
\hline Parameter & Unit & Value \\
\hline Density & $\mathrm{g} / \mathrm{cm}^{3}$ & 1.82 \\
Particle size & $\mathrm{nm}$ & $60-83$ \\
Micropore volume & $\mathrm{m}^{3} / \mathrm{g}$ & 0.012 \\
BET surface area & $\left(\mathrm{m}^{2} / \mathrm{g}\right)$ & 16.85 \\
Solubility @ $\left(20^{\circ} \mathrm{C}\right)$ & $\%$ & Insoluble \\
\hline
\end{tabular}


Table 2 Chemical composition of the nanoadsorbent

\begin{tabular}{llllll}
\hline Element & Weight \% & Atomic \% & Element & Weight \% & Atomic \% \\
\hline $\mathbf{O}$ & 43.04 & 63.68 & $\mathrm{Si}$ & 4.1 & 2.23 \\
$\mathbf{N a}$ & 4.06 & 4.26 & $\mathrm{Sr}$ & 1.25 & 1.17 \\
$\mathbf{C l}$ & 4.61 & 3.13 & $\mathrm{Al}$ & 2.3 & 1.64 \\
$\mathrm{Ca}$ & 17.1 & 10.28 & $\mathbf{M g}$ & 0.78 & 0.43 \\
$\mathrm{Fe}$ & 9.46 & 4.08 & $\mathbf{S}$ & 1.5 & 1.95 \\
$\mathbf{A u}$ & 0.31 & 0.04 & $\mathbf{K}$ & 1.18 & 1.15 \\
$\mathbf{C}$ & 10.31 & 5.97 & Total & 100 & 100 \\
\hline
\end{tabular}

information are achieved on the use of the shell as adsorbent. Considering the possibility of successful production of air-stable ZVI nanoparticles with a high gravimetric ratio, good stability and no harmful matters, that in this research, it was studied as a bases for NZVI.

This study focused on the oyster shell supported NZVI application for the removal of NOMs under different experimental conditions, in order to remove taste and odor-causing agents from surface water resources.

\section{Methods}

\section{Stock solutions}

In this study, HA was used as NOMs representative and stock solution of HA was prepared using $1 \mathrm{~g}$ of HA powder dissolved in $1 \mathrm{~L}$ of deionized water, followed by filtering the solution through a $0.45 \mu$ membrane filter (cellulose acetate). The solution was further diluted to the required concentrations and were stored at $4{ }^{\circ} \mathrm{C}$ before application.

\section{Preparation of nano-supported shell}

The formation of the oyster shell supported iron nanoadsorbent was carried out by wet impregnation technique [26-29]. Shells collected from the coast of the Persian Gulf were transported to research lab and after physically cleaning (removal of mud, rinsing for $10 \mathrm{~min}$ and washing by deionized water), were crushed, dried in $100^{\circ} \mathrm{C}$ oven and then sieved with a mesh of 100. To prepare the NZVI coated shell, the shell beads were placed in the reactor during the synthesis of NZVI, by using the reduction of dissolved iron method, which comprised of four stages; mixing, separating, washing and drying [30,31].

Initially, $5 \mathrm{~g}$ of crushed shell beads were poured in a flask containing $0.1 \mathrm{M} \mathrm{FeCl} 3-6 \mathrm{H} 2 \mathrm{O}$ dissolved in absolute ethanol and heated up to $80^{\circ} \mathrm{C}$ until the solvent was evaporated and dry coated beads were obtained. The beads were dispersed in $150 \mathrm{~mL}$ flask containing absolute ethanol and then the flask was placed on an orbital shaker. One hundred $\mathrm{mL}$ of $0.16 \mathrm{M} \mathrm{NaBH} 4$ aqueous solution was poured into a burette and dropped into stirring flask. During this reaction, ferric iron $\left(\mathrm{Fe}^{3+}\right)$ was reduced to zero-valent iron $\left(\mathrm{Fe}^{0}\right)$ by borohydride and the crushed shell beads started to take black color. This suggested that the ferrous ions attached to the support material were successfully reduced to zerovalent state, according to the following reaction:

$$
\begin{aligned}
& \mathrm{Fe}^{2+}+2 \mathrm{BH}_{4}^{-}+6 \mathrm{H}_{2} \mathrm{O} \rightarrow \mathrm{Fe}^{0}+2 \mathrm{~B}(\mathrm{OH})_{3} \\
& \quad+7 \mathrm{H}_{2}{ }^{\uparrow}
\end{aligned}
$$

Afterwards, the contents of the flask were discharged to a funnel containing a millipore filter, under the suction force, leading to dewatering. The shell beads coated with NZVI were washed by ethanol, and then dried at $50^{\circ} \mathrm{C}$ and then kept in desiccators.

\section{Characterization of nanoadsorbent}

Laboratory synthesized nanoadsorbent was analyzed using Scanning Electron Microscopy (SEM) of TESCAN, Energy Dispersive Spectroscopy (EDS) and X-Ray Fluorescence (XRF). The specific surface area of nanoadsorbent was analyzed using BET- $\mathrm{N}_{2}$ adsorption method.

\section{Batch reactor adsorption system and experiments}

Adsorption of HA onto produced adsorbent was carried out by a batch reactor and effect of different parameters such as initial HA concentration, adsorbent dose, $\mathrm{pH}$, and temperature were studied.

\section{Adsorption isotherm}

Different doses of nanoadsorbent $(0.5 \mathrm{gr}, 1 \mathrm{gr}, 3 \mathrm{gr}$ and $5 \mathrm{gr})$ were added to the reaction flask containing 100 $\mathrm{mL}$ of $5 \mathrm{mg} / \mathrm{L}$ HA solution with the initial $\mathrm{pH}$ of 7 and temperature of $25^{\circ} \mathrm{C}$. The containers were sampled:

Table 3 Chemical composition of the nanoadsorbent

\begin{tabular}{llllllll}
\hline Composition & \% Weight & Composition & \% Weight & Composition & \% Weight & Composition & \% Weight \\
\hline $\mathrm{SiO} 2$ & 1.21 & $\mathrm{Al} 2 \mathrm{O} 3$ & 0.37 & $\mathrm{MgO}$ & 0.71 & $\mathrm{Na} 2 \mathrm{O}$ & 1.01 \\
$\mathrm{CaO}$ & 21.09 & $\mathrm{~K} 2 \mathrm{O}$ & 0.65 & $\mathrm{Cl}$ & 0.07 & $\mathrm{SO}$ & 0.19 \\
$\mathrm{FeOOH}$ & 4.01 & $\mathrm{CaCO}$ & 63.38 & $\mathrm{SrO}$ & 0.81 & $\mathrm{Fe} 2 \mathrm{O} 3$ & 5.51 \\
\hline
\end{tabular}




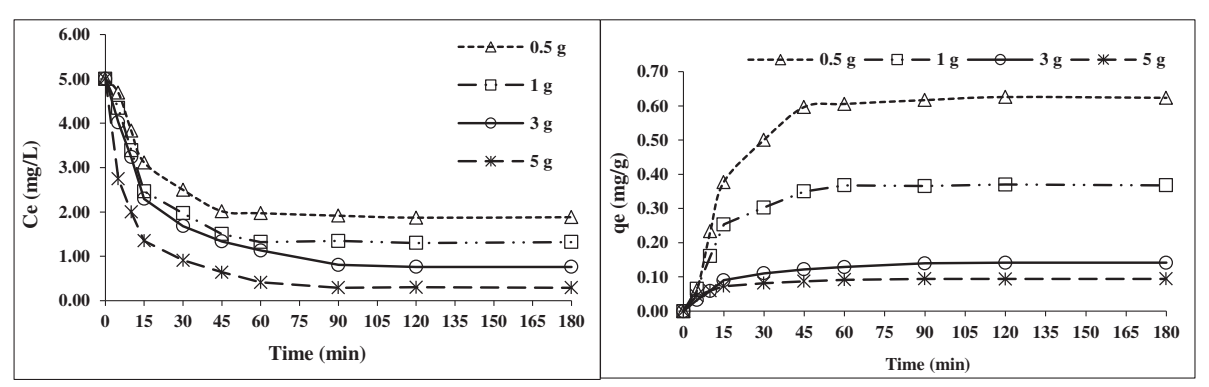

Figure 2 The effect of the adsorbent dose @ (HA $=5 \mathrm{mg} / \mathrm{L}, \mathrm{Temp}=25^{\circ} \mathrm{C}$ and $\left.\mathrm{pH}=7\right)$.

firstly at intervals of 5 and $10 \mathrm{~min}$ and then at a frequency of every $15 \mathrm{~min}$ to reach equilibrium time. After shaking and settling for $5 \mathrm{~min}$, the samples supernatant were centrifuged followed by membrane filter $(0.45 \mu \mathrm{m}$, cellulose acetate), absorbance values of solutions remaining without adsorption were measured by using UV-Vis spectrophotometer at wavelength of $254 \mathrm{~nm}$. In the next step, adsorption equilibrium data were correlated with two well-known empirical isotherm models; Freundlich and Langmuir.

\section{The kinetic of HA adsorption}

After determining the adsorption isotherm, using collected data and models related to the absorption kinetics, modeling kinetic of HA adsorption study on the nanoadsorbent was determined.

\section{The effect of initial HA concentration}

The effect of initial HA concentration on the adsorption rate was studied by contacting $0.5 \mathrm{~g}$ of adsorbent at room temperature of $25^{\circ} \mathrm{C}$ and $\mathrm{pH}=7$ using four initial concentrations of $\mathrm{HA}$ solution $(0.5,2,5$ and $10 \mathrm{mg} / \mathrm{L}$ ) in $100 \mathrm{~mL}$ of samples at time $=0$ and at selected time intervals (up to a maximum of $180 \mathrm{~min}$ ), sample concentration was determined by UV-Vis spectrophotometer.

\section{The effect of $\mathrm{pH}$}

In order to survey the $\mathrm{pH}$ effect on $\mathrm{HA}$ adsorption, $\mathrm{pH}$ of the solution was changed in the range of 5.0 and 10.0 at four intervals $(5,7,8$ and 10) using either $0.1 \mathrm{~mol} / \mathrm{L}$ $\mathrm{NaOH}$ or $0.1 \mathrm{~mol} / \mathrm{L} \mathrm{HCl} \mathrm{pH}$ values were determined using a Elmetron CP-501 pH meter, fitted with a combined glass-reference electrode.

\section{The effect of temperature}

In order to assess the effect of temperature on the equilibrium adsorption capacity of HA, $0.5 \mathrm{gr}$ of the nanoadsorbent was used at different temperatures $(25,30$ and $40^{\circ} \mathrm{C}$ ), with $5 \mathrm{mg} / \mathrm{L} \mathrm{HA}$ solutions, optimum $\mathrm{pH}=5$ and in equilibrium contact time.

\section{Results and discussion}

\section{Characterization of nanoadsorbent}

SEM image of the nanoadsorbent is shown in Figure 1, the physical properties of the nanoadsorbent are presented in Table 1, the chemical elements and composition of nanoadsorbent are presented in Tables 2 and 3, respectively.

As shown in the Figure 1, most of the sheet structure has been changed to irregular small particles and depicts the synthesized nanoadsorbent with an approximately 60-85 nm diameter. The main elements of the adsorbent were $\mathrm{Ca}, \mathrm{O}, \mathrm{Fe}$ and $\mathrm{Na}$ and as it can be found from Table 3, the highest component of the adsorbents was
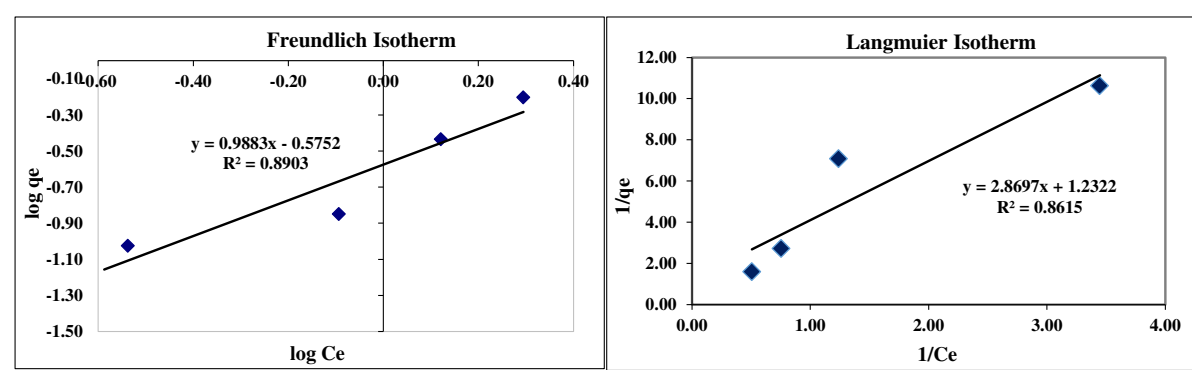

Figure 3 Freundlich and Langmuir adsorption isotherms. 

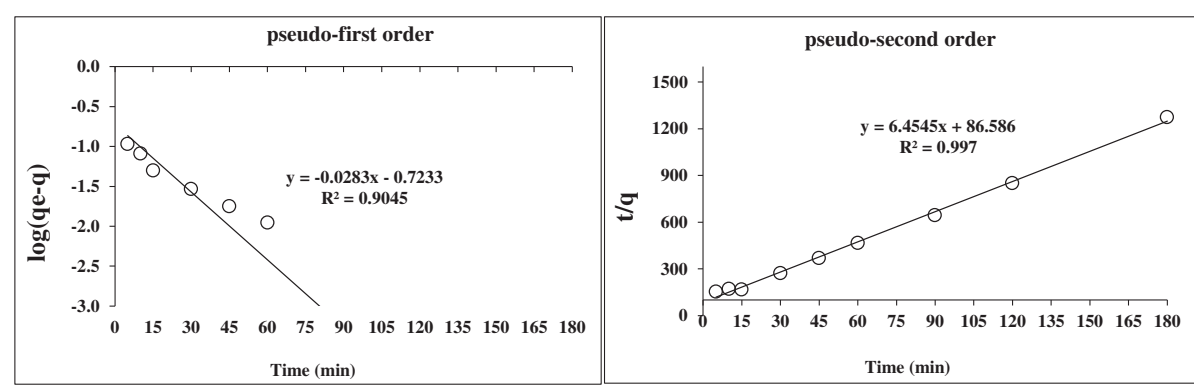

Figure 4 Adsorption kinetics; pseudo-first order and pseudo-second order (nanoadsorbent dose $=3 \mathrm{~g} / 100 \mathrm{~mL}, \mathrm{CO}=5 \mathrm{mg} / \mathrm{l}, \mathrm{Temp}=25^{\circ} \mathrm{C}$ and $\mathrm{pH}=7)$.

lime $\left(\mathrm{CaCO}_{3}\right.$ and $\left.\mathrm{CaO}\right)$, whit about $94.25 \%$ of the total weight.

\section{The effect of the adsorbent dose}

The effect of the initial HA concentration on its adsorption is shown in Figure 2. Although by increasing the nanoadsorbent dose of 0.5 to $10 \mathrm{mg} / \mathrm{L}$, the removal of HA $(\mathrm{C}=5 \mathrm{mg} / \mathrm{L})$ was found to increase from $66.4 \%$ to $97.4 \%$, the amount of removed HA (mg) per mass of nanoadsorbent showed a decrease in the rate from $0.66 \mathrm{mg} / \mathrm{g}$ to $0.09 \mathrm{mg} / \mathrm{g}$. This is because of the fact that increasing adsorbent dosage increases the surface area for adsorption. However, very slow increase in the removal was observed beyond the dose of $3 \mathrm{~g} / \mathrm{L}$. This section of our results was in accordance with a study of Doulia etal who studied the adsorption of humic acid on acid-activated Greek bentonite [13].

The data of adsorption equilibrium for HA adsorption by nanoadsorbent are presented in Figures 2 and 3. As it can be seen, Freundlich isotherm had a better correlation with HA removal with $\mathrm{R}^{2}$ higher than Langmuir. The $\mathrm{r}$-shaped adsorption isotherm indicated that there is a high affinity of contact time with adsorption rate.

\section{Kinetic of HA adsorption}

Adsorption kinetics of $\mathrm{HA}$ as pseudo-first order and pseudo-second order are depicted in Figure 4.

Based on results of Figure 4, the pseudo second order model generates better fit to the experimental data of the investigated adsorption of HA on nanoadsorbent $\left(R^{2}=0.997\right)$. The degree of the reaction is determined by sharing or exchange of electrons between adsorbent positive (nzvi) and negative groups (HA).

\section{The effect of initial HA concentration}

The effect of initial HA concentration is depicted in Figure 5. It can be observed that the removal rate of HA decreased from 0.64 to 0.84 , by increasing the initial HA concentration from 0.5 to $10 \mathrm{mg} / \mathrm{L}$. The equilibration time for the adsorption of $\mathrm{HA}$ at different concentrations ranged between 90 and $120 \mathrm{~min}$ for 0.5 an10 $\mathrm{mg} / \mathrm{L}$ of $\mathrm{HA}$, respectively.

As can be seen from Figure 5 when an increase occurs in the initial concentrations, the adsorption capacity of HA would enhance. Driving force is one of the most important factors in the adsorption process so the adsorption capacity of HA is a function of HA initial concentration, as it is important to overcome

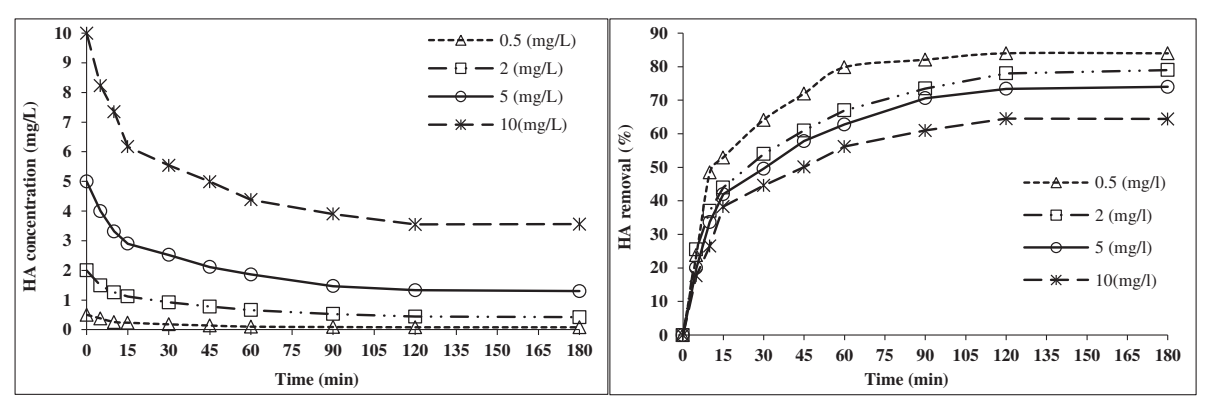

Figure 5 The effect of initial HA concentration and contact time on HA removal by nanoadsorbent @ (nanoadsorbent dose: $0.5 \mathrm{~g} / 100 \mathrm{~mL}$, Temp $=25^{\circ} \mathrm{C}$ and $\mathrm{pH}=7$ ). 


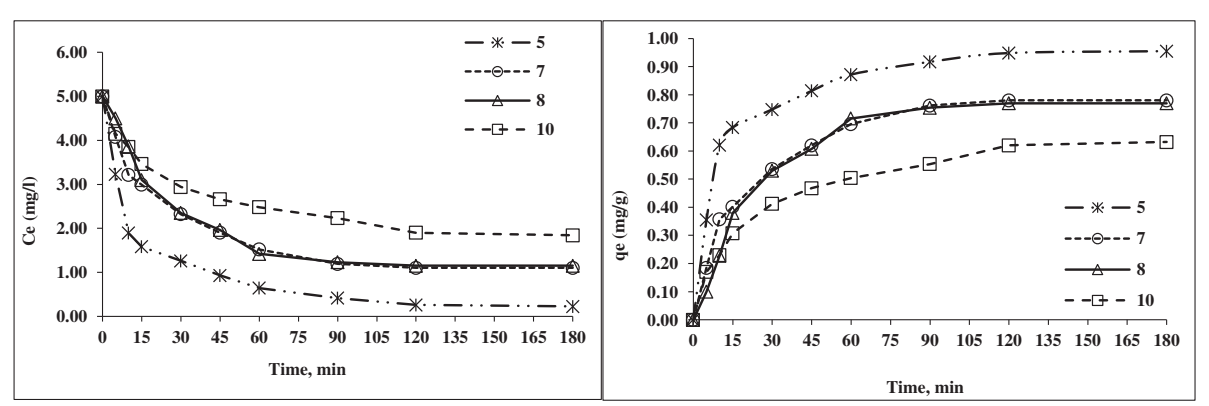

Figure 6 The effect of $\mathrm{pH}$ and contact time on HA removal by nanoadsorbent $(\mathrm{HA}=5 \mathrm{mg} / \mathrm{L}$, nanoadsorbent dose $=0.5 \mathrm{~g} / 100 \mathrm{~mL}$ and Temp $=25^{\circ} \mathrm{C}$ ).

the mass transfer resistance of the HA between the adsorbate and the adsorbent. In other words, the increase in the mass driving force allows more HA molecules to pass from the solution to the adsorbent surface. Therefore there is an inverse relationship between initial concentration and adsorption capacity [32]. This finding were in accordance with Moussavi et al [3] who investigated adsorption characteristics of $\mathrm{HA}$ onto single-walled carbon nanotubes and reported that the amount of adsorbed HA was higher at lower initial concentrations of HA.

\section{The effect of $\mathrm{pH}$}

The effect of the initial $\mathrm{pH}$ on adsorption rate is presented in Figure 6. As it can be seen, a maximum HA adsorption rate of $0.96 \mathrm{mg}$ per gram of adsorbent was observed at $\mathrm{pH}=5$. This was followed by a decrease in adsorption capacity at the late stage of $\mathrm{pH}$ experiments ranging from 5 to 10 . Also the minimum adsorption capacity was found to be $0.63 \mathrm{mg} / \mathrm{g}$ at initial $\mathrm{pH}=10$ after reaching the equilibrium time (120 min). Adsorption of HA to nanoadsorbent is strongly influenced by $\mathrm{pH}$. As increasing the $\mathrm{pH}$ increases the ionization of HA and hence the concentration of the negatively charged ions which leads to decreasing the amount of $\mathrm{H}^{+}$ions [33].

\section{The effect of temperature}

The temperature effect on the HA adsorption on nanoadsorbent is shown in Figure 7, with HA concentration of $5 \mathrm{mg} / \mathrm{L}$, the adsorption rate increased from $76.8 \%$ to $91.4 \%$, by increasing the temperature from $25^{\circ} \mathrm{C}$ to $40^{\circ} \mathrm{C}$. As depicted in Figure 7, temperature increase led to further the HA adsorption, due to high interaction between HA and ZNVI-shell beads. The temperature increasing creates swelling effect in the internal structure of the adsorbent, causing further penetration HA into the adsorbent [34]. In addition, temperature increase causes more diffusion rate of HA molecules in the external boundary layer and the internal pores of the adsorbent particles. Our finding was in accordance with Zeinali etal results on adsorption of dichloromethane using GAC [35].

\section{Conclusions}

The obtained results revealed that surface area and pore volume of nanoadsorbent were $16.85\left(\mathrm{~m}^{2} / \mathrm{g}\right)$ and $0.021 \mathrm{~m}^{3} / \mathrm{g}$, respectively; the main elements of the adsorbent were
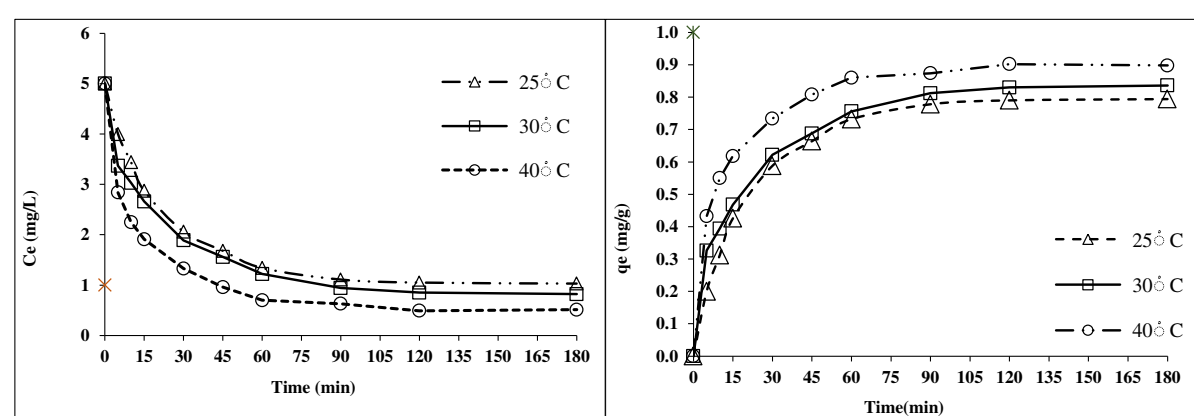

Figure 7 The effect of temperature and contact time on $\mathrm{HA}$ removal by nanoadsorbent (HA= $5 \mathrm{mg} / \mathrm{L}$, nanoadsorbent dose $=0.5 \mathrm{~g} / 100 \mathrm{~mL}$ ). 
$\mathrm{Ca}, \mathrm{O}, \mathrm{Fe}$ and $\mathrm{Na}$ and most of the adsorbent component was composed of lime $\left(\mathrm{CaCO}_{3}\right.$ and $\mathrm{CaO}$ about $94.25 \%$ of the total weight). The produced nanoadsorbent was not soluble in water. HA Adsorption onto the nanoadsorbent increased by increasing of adsorbent dose and temperature and decreased by increasing HA concentration and $\mathrm{pH}$. The $\mathrm{r}$-shaped adsorption isotherm indicated a high affinity of contact time with adsorption rate. In optimal conditions provided in the study ( $\mathrm{HA}=$ $5 \mathrm{mg} / \mathrm{L}$, nanoadsorbent dose $=0.5 \mathrm{~g} / 100 \mathrm{~mL}, \mathrm{pH}=5$ and temperature $=40^{\circ} \mathrm{C}$ ), maximum HA removal efficiency reached to $94.6 \%$, within $90-120 \mathrm{~min}$ at the experimental conditions in all cases is Pseudo-second order and Freundlich isotherm models were fitted to the adsorption kinetic and isotherm, respectively.

\section{Competing interests}

The authors declare that they have no competing interests.

\section{Authors' contributions}

VA conducted the practical parts of the study and wrote the first draft of the manuscript. AR had shared roles in nanoadsorbrnt characterization. SN, AHM, and RNN participated in data analysis and provided comments during the writing of the manuscript. All authors read and approved the final manuscript.

\section{Acknowledgements}

The authors are grateful to the Dr Elham Boushehri and Mrs. Afsoon Pirouzan, Hormozgan University of Medical Sciences, as well as all laboratory staffs of the Departments of Environmental Health Engineering in both Hormozgan University of Medical Sciences and Tehran University of Medical Sciences.

\section{Author details}

'Department of Environmental Health Engineering, School of Public Health, Tehran University of Medical Sciences, Tehran, Iran. ${ }^{2}$ Center for Water Quality Research (CWQR), Institute for Environmental Research (IER), Tehran University of Medical Sciences, Tehran, Iran. ${ }^{3}$ Nanotechnology Research Center, Research Institute of Petroleum Industry (RIPI), Tehran, Iran.

Received: 4 August 2014 Accepted: 6 December 2014

Published online: 19 December 2014

\section{References}

1. Yue Z, Economy J: Nanoparticle and nanoporous carbon adsorbents for removal of trace organic contaminants from water. J Nanoparticle Res 2005, 7:477-487.

2. Mahvi AH, Alipour $\mathrm{V}$, Rezaei L: Atmospheric moisture condensation to water recovery by home air conditioners. Am J Appl Sci 2013, 10(8):917-923.

3. Moussavi G, Talebi S, Farrokhi M, Mojtabaee Sabouti R: The investigation of mechanism, kinetic and isotherm of ammonia and humic acid co-adsorption onto natural zeolite. Chem Eng J 2013, 171:1159-1169.

4. Bai $R$, Zhang $X$ : Polypyrrole-coated granules for humic acid removal. J Colloid Interface Sci 2001, 243:52-60.

5. Schmitt D, Saravia F, Frimmel FH, Schuessler W: NOM facilitated transport of metal ions in aquifers: importance of complex-dissociation kinetics and colloid formation. Water Res 2003, 37:3541-3550.

6. Yuan W, Zydney AL: Humic acid fouling during ultrafiltration. Environ Sci Technol 2000, 34:5043-5050.

7. Klausen J, Vikesland PJ, Kohn T, Burris DR, Ball WP, Roberts AL: Longevity of granular iron in groundwater treatment processes: solution composition effects on reduction of organohalides and nitroaromatic compounds. Environ Sci Technol 2003, 37:1208-1218.

8. Tratnyek PG, Scherer MM, Deng B, Hu S: Effects of natural organic matter, anthropogenic surfactants, and model quinones on the reduction of contaminants by zero- valent iron. Water Res 2001, 35:4435-4443.
9. Bansal RC, Goyal M: Activated carbon adsorption. New York: Taylor \& Francis Group; 2005.

10. Jonglertjunya $W$, Lertchutimakul $T$ : Equilibrium and kinetic studies on the adsorption of humic acid by activated sludge and Bacillus subtilis. Songklanakarin J Sci Technol 2012, 34(6):669-677.

11. Giasuddin AM, Kanel S, Choi HC: Adsorption of Humic Acid onto Nanoscale Zerovalent Iron and Its Effect on Arsenic Removal. Environ Sci Technol 2007, 41:2022-2027.

12. Harman Bl, Koseoglu H, Yigit NO, Beyhan M, Kitis M: The use of iron oxide-coated ceramic membranes in removing natural organic matter and phenol from waters. Desalination 2010, 261:27-33.

13. Doulia D, Leodopoulos C, Gimouhopoulos K, Rigas F: Adsorption of humic acid on acid-activated Greek bentonite. J Colloid Interface Sci 2009, 340:131-141.

14. Kabsch-Korbutowicz M: Effect of Al coagulant type on natural organic matter removal efficiency in coagulation/ultrafiltration process. Desalination 2005, 185(1-3):327-333.

15. Bolto B, Dixon D, Eldridge R, King S, Linge K: Removal of natural organic matter by ion exchange. Water Res 2002, 36(20):5057-5065.

16. Zazouli MA, Nasseri S, Mahvi AH, Gholami M, Mesdaghinia AR, Younesian M: Retention of humic acid from water by nanofiltration membrane and influence of solution chemistry on membrane performance. Iran J Environ Health Sci Eng 2008, 5(1):11-18.

17. Selcuk H, Rizzo L, Nikolaou AN, Meric S, Belgiorno V, Bekbolet M: DBPs formation and toxicity monitoring in different origin water treated by ozone and alum/PAC coagulation. Desalination 2007, 210(1-3):31-43.

18. Leiknes T, Lazarova M, Odegaard H: Development of a hybrid ozonation biofilm-membrane filtration process for the production of drinking water. Water Sci Technol 2005, 51(6-7):241-248.

19. Mahvi AH, Maleki A, Rezaee R, Safari M: Reduction of humic substances in water by application of ultrasound waves and ultraviolet irradiation. Iran J Environ Health Sci Eng 2009, 6(4):233-240.

20. Ho L, Newcombe G: Effect of NOM, turbidity and floc size on the PAC adsorption of MIB during alum coagulation. Water Res 2005, 39(15):3668-3674.

21. Li Q, Mahendra S, Lyon DY, Brunet L, Liga MV, Li D, Alvarez PJ: Antimicrobial nanomaterials for water disinfection and microbial control: Potential applications and implications. Water Res 2008, 4(18):4591-4602.

22. Savage N, Diallo MS: Nanomaterials and water purification: Opportunities and challenges. J Nanoparticle Res 2005, 7(4-5):331-342.

23. Bezbaruah AN, Shanbhogue SS, Simsek S, Khan E: Encapsulation of iron nanoparticles in alginate biopolymer for trichloroethylene remediation. J Nanoparticle Res 2011, 13:6673-6681.

24. Dickinson M, Scott TB: The application of zero valent iron nanoparticles for the remediation of a uranium-contaminated waste effluent. J Hazard Mater 2010, 178:171-179.

25. Park H, Yeon KH, Park YM, Lee SJ, Lee SH, Choi YS, Chung Y: Reduction of nitrate by nanoscale zero-valent iron supported on mesoporous silica beads. J Water Environ Technol 2008, 6(1):35-42.

26. Petala E, Baikousi M, Dimos K, Filip J, Pechousek J, Tucek J, Safarova K, Douvalis A, Bakas T, Karakassides ZM, Zboril R: Zero valent iron nanoparticles supported on porous matrices: enhanced efficiency and application for water treatment. $J$ Hazard Mater 2013, 261:295-306.

27. Liu T, Zhao L, Sun D, Tan X: Entrapment of nanoscale zero-valent iron in chitosan beads for hexavalent chromium removal from wastewater. J Hazard Mater 2010, 184(1-3):724-730.

28. Zhang $X$, Lin $S$, Lu XQ, Chen Zl: Removal of $\mathrm{Pb}$ (II) from water using synthesized kaolin supported nanoscale zero-valent iron. Chem Eng J 2010, 163:243-248.

29. WZW Yaacob, Kamaruzaman N, Samsudin AR: Development of nano-zero valent iron for the remediation of contaminated water. Chemical engineering transactions 2012, 28:25-30.

30. Pan BC, Chen BJ, Meng XQ, Pan XT, Li MW, Zhang X, Zhang JL, Chen AB, Zhang $X Q$, Sun $Y$ : Application of an effective method in predicting breakthrough curves of ?xed bed adsorption onto resin adsorbent. J Hazard Mater 2005, B, 124:74-80.

31. Wan Ngah WS, Kamari A, Koay YJ: Equilibrium and kinetic studies of adsorption of copper (II) on chitosan and chitosan/PVA beads. Int I Biol Macromol 2004, 3:155-161. 
32. Perez-Aguilar NV, Diaz-Flores PE, Rangel-Mendez JR: The adsorption kinetics of cadmium by three different types of carbon nanotubes. J Colloid Interface Sci 2011, 364:279.

33. Bringle CD, Shibi IG, Vinod VD, Anirudhan TS: Sorption of humic acid from aqueos solutions by lanthana alumina oxide pillared bentonite. J Sci Ind Res 2005, 46:782-788.

34. Zulfikar MA: Effect of Temperature on Adsorption of Humic Acid from Peat Water onto Pyrophyllite. International Journal of Chemical, Environmental \& Biological Sciences, 2013, 1(1):88-90.

35. Zeinali F, Ghoreyshi A, Najafpour DD: Adsorption of dichloromethane from aqueous phase using granular activated carbon; Isotherm and breakthrough curve measurements. Middle East I Sci Res 2010, 5(4):191-198.

\section{Submit your next manuscript to BioMed Central and take full advantage of:}

- Convenient online submission

- Thorough peer review

- No space constraints or color figure charges

- Immediate publication on acceptance

- Inclusion in PubMed, CAS, Scopus and Google Scholar

- Research which is freely available for redistribution 